\title{
Lorrie Moore: Mo(o)re than an interim assessment
}

\author{
Article \\ Published Version
}

Brauner, D. and MacPherson, H. S. (2012) Lorrie Moore: $\mathrm{Mo}(0)$ re than an interim assessment. Journal of American Studies, 46 (3). pp. 541-550. ISSN 1469-5154 doi: https://doi.org/10.1017/S0021875811001927 Available at https://centaur.reading.ac.uk/28977/

It is advisable to refer to the publisher's version if you intend to cite from the work. See Guidance on citing.

To link to this article DOI: http://dx.doi.org/10.1017/S0021875811001927

Publisher: Cambridge University Press

All outputs in CentAUR are protected by Intellectual Property Rights law, including copyright law. Copyright and IPR is retained by the creators or other copyright holders. Terms and conditions for use of this material are defined in the End User Agreement.

\section{www.reading.ac.uk/centaur}

\section{CentAUR}

Central Archive at the University of Reading

Reading's research outputs online 


\title{
Journal of American Studies
}

http://journals.cambridge.org/AMS

Additional services for Journal of American

\section{Studies:}

Email alerts: $\underline{\text { Click here }}$

Subscriptions: $\underline{\text { Click here }}$

Commercial reprints: $\underline{\text { Click here }}$

Terms of use : $\underline{\text { Click here }}$

\section{Lorrie Moore Collection Lorrie Moore: Mo(o)re than an Interim Assessment}

\author{
DAVID BRAUNER and HEIDI SLETTEDAHL MACPHERSON
}

Journal of American Studies / Volume 46 / Issue 03 / August 2012, pp 541 - 550

DOI: 10.1017/S0021875811001927, Published online: 14 August 2012

Link to this article: http://journals.cambridge.org/abstract_S0021875811001927

How to cite this article:

DAVID BRAUNER and HEIDI SLETTEDAHL MACPHERSON (2012). Lorrie Moore Collection Lorrie Moore: Mo(o)re than an Interim Assessment. Journal of American Studies,46, pp 541-550 doi:10.1017/S0021875811001927

Request Permissions : $\underline{\text { Click here }}$ 


\title{
Lorrie Moore Collection Lorrie Moore: $\mathrm{Mo}(\mathrm{o})$ re than an Interim Assessment
}

\author{
DAVID BRAUNER AND \\ HEIDI SLETTEDAHL MACPHERSON
}

Lorrie Moore has long shed the image of the precocious talent who won the Seventeen story prize with her first submission as a nineteen-year-old undergraduate, but there is still a sense that her best work may be yet to come. In that respect, this mini special issue represents by no means the final word on Moore, but rather an interim assessment of a career that is already substantial and that promises much more to come. Together these three essays (and introduction) offer a coherent and striking exploration of Moore's work that develops new directions for future criticism and will help cement her growing reputation as one of the most original and distinctive contemporary writers. They sometimes circle around the same stories, even the same quotations, reading them in a variety of frames and picking up (and at) the nuances of Moore's sustained wordplay and careful documenting of space, of identity, of gender. Thus these essays work together rather than separately, layering over multiple understandings of Moore's incisive American literature.

Lorrie Moore has been called "America's first lady of darkness and mirth," title that hints at the duality of her work, encompassing pathos and delight, sadness and humour. For over twenty-five years, Moore has been the master (or mistress) of the American short story, that iconic genre that so often characterizes American literature as a whole. She is a writers' writer, with plaudits and book blurbs from Dave Eggers, Helen Simpson, David Lodge, Nick Hornby, Roddy Doyle, Julian Barnes, Alison Lurie and Jonathan Lethem, amongst others. Hornby calls her "the best American writer of her generation," while Eggers commends her juxtaposition of humour and pain: "While fascinated almost exclusively with broken people, she is one of the funniest writers alive." 2 Moore's ability to "juggle everyday outrage and high tragedy with a hand so deft that her most poignant passages are often also the

David Brauner, Department of English Language and Literature, University of Reading. Email: d.brauner@reading.ac.uk. Heidi Slettedahl Macpherson, Pro Vice-Chancellor, Research and Innovation, De Montfort University. Email: hmacpherson@dmu.ac.uk.

${ }^{\text {I }}$ Robert McCrum, The Observer, io April 20 Io.

${ }^{2}$ See the dust jacket of Faber and Faber hardback edition of The Collected Stories for these and other plaudits. 
most hilarious or sardonic," as Elizabeth Gaffney put it, ${ }^{3}$ to combine what Robert Chodat has called a "keen sense of the absurd" with a sense of "existential terror," is one of her greatest strengths as a writer and at the same time arguably one of the reasons for her marginal status in the canon of contemporary authors. ${ }^{4}$ A self-styled feminist who has been accused of "deficient feminism" and who often satirizes tensions between feminist theory and practice in her fiction, 5 the author of experimental fiction that is at the same time committed to realism, Moore is an elusive figure, a difficult writer to pin down in an age when conformity to a recognizable brand seems to be prized, in academia as much as in the marketplace. ${ }^{6}$

Moore is the award-winning American author of three collections of short stories: Self-Help (1985), Like Life (1988) and Birds of America (1998). These stories, along with three stories originally published in the New Yorker, were published by Faber and Faber as The Collected Stories (2008). Though primarily known for her short stories, Moore has also turned her hand to novels, publishing Anagrams, an experimental novel that incorporates short stories (1 986), Who Will Run the Frog Hospital? (1994), and, most recently, her long-awaited 9/ I I novel, $A$ Gate at the Stairs (2009). This latest novel was shortlisted for the coveted Orange Prize and the PEN/Faulkner award and became an unexpected best seller in the United States. Moore won the O. Henry Award in 1998 and the Rhea Award for the Short Story in 2004, and in 2006 was elected to the American Academy of Arts and Letters. She has toured the UK twice in recent years, with highlights including a guest lecture at the Rothermere American Institute (Oxford) in 2008 and an event ("In Conversation with Lorrie Moore") at the British Library in 2010. As further evidence of her status in the UK, The Collected Stories was featured in John Mullan's Guardian Book Club series (the first short-story collection to be included). Jonathan Lethem, in the New York Times, wrote, "On finishing 'A Gate at the Stairs' I turned to the reader nearest to me and made her swear

${ }^{3}$ Elizabeth Gaffney, "Lorrie Moore: The Art of Fiction CLXVII," Paris Review, I 58 (Spring/ Summer 200I), available at www.theparisreview.org/interviews/510/the-art-of-fiction-noI 67-lorrie-moore, accessed I March 20 I I.

${ }^{4}$ Robert Chodat, "Jokes, Fiction, and Lorrie Moore," Twentieth-Century Literature, 52, I (Spring 2006), 42-60, 42, 50.

${ }^{5}$ See Alison Kelly, Understanding Lorrie Moore (Columbia: University of South Carolina Press, 2009), I 5 I- 52.

${ }^{6}$ Although herself a professor of English literature at the University of Wisconsin, Moore's fiction contains several jibes at academic discourse, notably when Olena, the protagonist of the story "Community Life" in Birds of America, refers to literary theory as "the vocabulary of arson" (59). Elsewhere in the collection academic publishing is described as "a big Circle Jerk." 
to read it immediately"; 7 Ron Charles, in the Washington Post, warned readers to "Get ready to expand your sense of what [Moore] - and a novel - can do"; ${ }^{8}$ and Michiko Kakutani, the doyenne of American fiction reviewers, paid tribute to its "enormous emotional precision," calling it a "heartbreaking novel" with a "searing conclusion." In an article in the news section of The Observer under the headline "Literary Recluse Charms US Critics after a I 5 -Year Wait," Paul Harris reported on this "ecstatic" reception of $A$ Gate at the Stairs in "American literary circles." Choosing to ignore her continuing output of short fiction, Harris asks, "where has Moore been for the last decade and a half?" before noting that a "painful divorce" and the "drain on her time" of "raising her adopted black son" have partly accounted for her "long absence." He then quotes Moore herself, who responds to the question about the prolonged gestation of $A$ Gate at the Stairs with characteristic wry humour:

I was captured by space aliens... I have a list of prosaic reasons and excuses, such as being a working, single, book-reviewing mum, but I grow vaguely but perceptibly hysterical when I recite them, so I've decided to go with the space alien tale. ${ }^{10}$

Moore's satirical comments on her low profile, and Harris's clichéd treatment of the material notwithstanding, the serious point that emerges from this piece is that the relatively long gaps between Moore's books and her preference for the short story have contributed to a critical neglect of her oeuvre. The recent publication of The Collected Stories and A Gate at the Stairs suggests that this will soon change, and in fact Moore's critical reputation and popular profile have never been higher. To date, however, there is relatively little substantial published criticism on her: there is only one book devoted to her work, Alison Kelly's Understanding Lorrie Moore (2009), and a handful of articles. Moore remains critically underrated, which some would argue is because of her inclination towards humour and her insistence on wordplay and punning. As Robert Chodat notes, "the question that has dominated the critical response to Moore has been how legitimate or probing her humor ultimately is, regardless of its target." accorded to Moore may also be due to the fact that while her oeuvre represents a self-consciously metafictional turn that is often linked to postmodernism,

${ }^{7}$ Jonathan Lethem, "Eyes Wide Open," review of $A$ Gate at the Stairs, New York Times, 27 Aug. 2009, available at www.nytimes.com/2009/08/30/books/review/Lethem-t.html, accessed 2 Sept. 20 I I.

${ }^{8}$ Ron Charles, untitled review of $A$ Gate at the Stairs, Washington Post, 2 Sept. 2009, www. washingtonpost.com/wp-dyn/content/article/2009/09/0I/AR2009090103858.html, accessed 2 Sept. 20 I I.

9 Michiko Kakutani, "First Time for Taxis, Lo Mein, and Loss," review of $A$ Gate at the Stairs, New York Times, 27 Aug. 2009, available at www.nytimes.com/2009/08/28/books/28book. html, accessed 2 Sept. 20 I I.

${ }^{10}$ Paul Harris, The Observer, 27 Sept. 2009, $37 . \quad{ }^{11}$ Chodat, 42. 
her work is not easily accommodated in that category. Above all, Moore's reputation as a short-story writer rather than a novelist places her at a disadvantage in the context of a literary establishment with a strong generic bias towards the novel, which is also arguably a gender bias, since women writers have historically often been, and continue to be, drawn to the short story. In this sense, Moore has been caught in something of a double bind: criticized by some for failing to write enough substantial pieces of fiction (that is, novels) and criticized by others for writing novels when she is better suited to the shorter form (some reviewers even going so far as to discourage her from attempting to write any more novels at all). Given that the opening section of Who Will Run the Frog Hospital? was published initially as a separate story and that a section of Anagrams appears in The Collected Stories, there is an argument for seeing $A$ Gate at the Stairs as Moore's first real novel.

Geoff Dyer began his laudatory review of $A$ Gate at the Stairs in The Observer by asking, "Did it matter - did it gnaw away at her - that that in spite of the high critical standing enjoyed by her stories, Lorrie Moore had not come up with the big novel by which writers, American ones especially, tend to be judged?" Although he argues that the novel triumphantly vindicates Moore, he nonetheless identifies what he calls her "determinedly lackadaisical way of proceeding" as symptomatic of her "hesitant engagement with the demands of a big novel," thereby implicitly reinforcing the image of Moore as a writer for whom novel-writing does not come naturally. ${ }^{12}$ Repeatedly asked in interviews about her views on the relative merits of the short story and novel, Moore displays an ambivalence that reflects both an aesthetic commitment to the shorter form and a pragmatic recognition of the fact that the novel takes precedence in the informal hierarchy of literary genres. In an interview with Salon in 1998, she conceded that she is "primarily a short story writer" but at the same time insisted that "now is not the time for me to say I'm not a novelist since I'm working on a novel," the ungainly double negative implicitly suggesting an enduring diffidence in her ability to sustain a career as a novelist. ${ }^{13}$ Similarly, in an interview in the Paris Review in $200 \mathrm{I}$, Moore on the one hand claimed that the short story is "a more magical form" than the novel, proceeding "more from inspiration than slogging," and on the other hand implied that it is the product of greater discipline than the longer form, since "[t]o write a short story, you have to be able to stay up all night," whereas "novels ... may proceed at a more leisurely or erratic pace." ${ }^{14}$

\footnotetext{
12 "A virtuouso performance," review of $A$ Gate at the Stairs, The Observer "Review" section, 27 Sept. 2009, 20.

${ }^{13}$ Dwight Garner, "Moore’s Better Blues," Salon, 27 Oct. 1998, available at www.salon.com/ books/int/1998/10/cov_27int2.html, accessed I March 20 I I.

${ }^{14}$ Gaffney.
} 
This ambivalence is also evident in her writings on other writers' work. In a review of the early stories of John Updike, for example, Moore suggests that "by dint of both quality and quantity he is American literature's greatest short-story writer, and arguably our greatest writer without a single great novel," "s the distinction that she confers on him in terms of his achievements in the short story being implicitly qualified by the absence from his oeuvre of a novelistic masterpiece. In her review of Ann Beattie's collection of stories, Park City, she pays tribute to her "unshakably intelligent, deep-hearted, long and unsurpassed devotion to the form" and finishes the piece with an extended encomium on Beattie's virtues as a writer:

No other writer manages such warmth and coolness simultaneously. In her work there are no loud noises or bright colors; there is little overt grief, rage, gloom or giddiness. Hers is a palette of compassionately wielded pastels, and her stories are watercolors of the highest order. Do the characters sometimes seem similar from story to story? The same can be said of every short-story writer who ever lived. Does the imaginative range seem limited? It is the same limited range Americans are so fond of calling Chekhovian. ${ }^{16}$

What Moore writes about Beattie here might apply equally to herself (indeed Alison Lurie has described her as "the nearest thing we have to Chekhov" ${ }^{17}$ ). As such, it is revealing that although it constitutes an implicit apologia for her own work, as well as a defence of the short-story form, the terms in which that defence is couched reinforce some of the reservations that have been expressed about the genre in general and Moore's work in particular, namely that many of the protagonists resemble each other, that the purview of the stories is essentially parochial and, finally, that the work is somehow insubstantial ("watercolours" that lack the solidity and depth of oil paintings, which is to say, according to the analogy, novels).

If Moore might be said to have internalized some of the prevailing prejudice against the short story, her work itself nonetheless disproves the notion that the short story is invariably "small, concise, precise," as her contemporary Amy Hempel, writing of her own work, puts it. ${ }^{18}$ As the title of Birds of America suggests, Moore is in fact as interested in anatomizing American life, in all its

\footnotetext{
is "Home Truths," review of John Updike, The Early Stories, 1953-1975, New York Review of Books, I I Aug. 2005, available at www.nybooks.com/articles/archives/2003/nov/20/hometruths, accessed I March 20 I I.

${ }^{16}$ Lorrie Moore, "A House Divided," review of Ann Beattie, Park City: New and Selected Short Stories, New York Times, 28 June, 1998, available at www.nytimes.com/books/98/o6/28/ reviews/980628.28moor.html, accessed I March 20 I I.

${ }^{17}$ Helena de Bertodano, "Lorrie Moore interview," The Telegraph, 7 Oct. 2009, available at www.telegraph.co.uk/culture/books/authorinterviews/6256085/Lorrie-Moore-interview.html, accessed I March 20 II.

${ }^{18}$ Quoted in Elaine Showalter, A Jury of Her Peers: American Women Writers from Anne Bradstreet to Annie Proulx (London: Virago, 2009), 547.
} 
diversity and variety, as an Updike or a Philip Roth. Moore herself noted that there is at work in the collection "the registration of a peculiarly American sense of exile-geographic and emotional" that constitutes a collective "de facto American portrait," ${ }^{9} 9$ while Alison Kelly calls it a "bird's-eye view of the nation" that encapsulates "representative aspects of American national life," demonstrating an "overt interest in the nation's demographics, ideologies, and mythologies." 20

Moore's fiction has always been implicitly political: her first collection of stories, Self-Help was, among other things, a satirical critique of the American culture of self-improvement, as manifested particularly in the extraordinary proliferation of popular-psychology books that claim to inform their readers how to do everything from winning friends and influencing people to feeling the fear and doing it anyway. However, her work has become increasingly overtly engaged with "American national life" since the publication of Birds of America, and has dealt with 9/I I and its legacy, Obama's election campaign and the ongoing military interventions in Iraq and Afghanistan.

Moore has also always been interested in sexual politics and her work has, in fact, been most commonly contexualized in terms of a predominantly female tradition of the American short story that owes more to Raymond Carver's influence than to Ernest Hemingway's. In A Jury of Her Peers, for example, Elaine Showalter situates her in relation to prolific exponents of the form, such as Joyce Carol Oates and Ann Beattie. Calling Moore's earliest work "surprising and fresh" because of its recognition of the gendered pattern of contemporary life, particularly for the single woman, Showalter sees Moore as part of a female-led renaissance of the American short story during the 1980 s, in which the form "enjoyed unprecedented scrutiny and prestige." ${ }^{2}$ Certainly, there are important affinities between Moore and a number of female American contemporaries: Amy Bloom, Louise Erdrich, Amy Hempel, Susan Minot and Jayne Anne Phillips are all authors who, like Moore, were born in the 1950 s and came to prominence in the 1980 os with collections of short stories that explored (predominantly) contemporary women's experience in a tragicomic mode. Moore herself has also explicitly acknowledged debts to an older generation of female authors, including Alison Lurie, who was her thesis adviser at Cornell where she did her MFA from 1980 to 1983; Alice Munro, arguably the greatest living exponent of the short-story form; and Margaret Atwood, who was her "favorite writer" as a young adult. ${ }^{22}$ Moore's account of

\footnotetext{
${ }^{19}$ Quoted in Karen Weekes, "Identity in the Short Story Cycles of Lorrie Moore," Journal of the Short Story in English, 39 (Fall 2002), 109-22, I 16.

${ }^{20}$ Kelly, Understanding Lorrie Moore, I 4I. $\quad{ }^{21}$ Showalter, 476, 477, 546.

${ }^{22}$ Caryn James, "Neither Winners Nor Wimps," interview with Lorrie Moore, www.nytimes. com/books/98/09/20/specials/moore-help.html, accessed I March 20 I I.
} 
the impact that reading Atwood had on her development as a writer seems to offer corroborating evidence for those critics who see her as a writer particularly "interested in feminine emergencies": 23 "For the first time I read fiction about women who were not goddesses or winners. In some ways they were victims, but they weren't wimps. They were stylish about their victimization." ${ }^{24}$

Certainly, Moore's earlier fiction tends to focus on what Janet R. Raiffa calls "the modern single woman's conflicting desires for independence and professional success," 25 and she has implicitly placed herself in the tradition of women writers whose careers are circumscribed by their domestic circumstances, telling Elizabeth Gaffney,

It's hardly news that it is difficult to keep the intellectual and artistic hum of your brain going when one is mired in housewifery. This is, I realize, an old complaint from women, but for working women everywhere it continues to have great currency. ${ }^{26}$

The debt to Munro is also in evidence, though Moore somewhat disavows this, ruefully noting that she only discovered the author after she had been writing for some time. ${ }^{27}$ However, their imagined landscapes offer useful comparisons. In, for example, Lives of Girls and Women (like Anagrams, considered a series of interrelated stories by some critics) and The Beggar Maid: Stories of Flo and Rose (also published as Who Do You Think You Are?), Munro offers the reader intelligent and restricted women, whose senses of place and space define their identities. Coral Ann Howells argues that Munro's fictions project the image of "domestic surfaces stretched over deep caves," a metaphor adapted from Munro's own metaphor of lives as "deep caves paved with kitchen linoleum." 28 If Moore's work is less often mined for its hidden depths (a playful preoccupation with surfaces revealing itself over and over again), her oeuvre nonetheless reveals how the contours of the domestic sphere shape the lives of the girls and women within it.

On the other hand, Moore's fiction has, from Birds of America onwards, featured male characters who are "as deeply realized and human as their female counterparts," ${ }^{29}$ and has arguably become less female-centric if not necessarily less feminist. This shift in emphasis is perhaps demonstrated by the fact that in an early review, Jay McInerney compared her to Grace Paley, ${ }^{30}$ whereas when the New York Times Book Review cited Birds of America as one of its books of

${ }^{23}$ Gaffney. $\quad{ }^{24}$ James.

${ }^{25}$ Janet R. Raiffa, “Lorrie Moore,” in Blanche H. Gelfant, ed. The Columbia Companion to the Twentieth-Century American Short Story (New York: Columbia University Press, 2000), 384-390, 387 . ${ }^{26}$ Gaffney. 27 Ibid.

${ }^{28}$ Coral Ann Howells, Private and Fictional Words: Canadian Women Novelists of the I97os and ig8os (London: Methuen, 1987), 73; Alice Munro, Lives of Girls and Women (New York: Plume, I 97 I), 249.

29 Raiffa, 389.

${ }^{\circ}$ Jay McInerney, "New and Improved Lives," New York Times, 24 March 1985, available at www.nytimes.com/books/98/09/20/specials/moore-help.html, accessed I March 20 I I. 
the year for 1998 , it noted that "Moore, like Samuel Beckett... sees that nothing is funnier than unhappiness." ${ }^{1}$

Rather than treating Moore exclusively as a woman writer or a novelist manqué, this collection of essays on Moore recognizes her pre-eminence in the canon of the short story and celebrates her increasingly central role in contemporary American letters. The essays explore the range of her comic wit and humour (particularly her wordplay), her focus on motherhood and the roles women adopt, and her fascination with ethnicity and pathos. It is for her wordplay that Moore is best known, and the first essay of this trio of essays examines Moore's fascination with language and the role it plays in meaning formation. Karen Weekes, who has written several articles on Moore and her work, argues that indulgence in wordplay is a chief marker of Lorrie Moore's prose. In "Words Are All You Need: Speech Acts in Lorrie Moore's Anagrams," Weekes employs speech act theory to examine how Moore's protagonists find refuge in words' multiple meanings. She argues that Moore's characters are shaped by their language and their response to others' words more than by their responses to events, giving speech acts more import than actual actions. Although all storytelling can be viewed as a type of speech act between author and reader, Moore's protagonists use speech acts as a respite from tension and interpersonal conflict, to the extent of using language to invent new characters, such as Georgianne and Eleanor in Anagrams. People in Moore's tales are rarely looking for the "right" consoling, helpful - words, Weekes suggests; they instead use language as a bandage to cover the wounds of failing, or failed, relationships. Speech acts ultimately prove fruitless in holding off the inevitable, and her characters are almost always alone at the end of their stories, both consoled and isolated by language.

The second essay also examines Anagrams, taking its title from one of the stories that makes up the novel/short-story cycle. "Escape from the Invasion of the Love-Killers': Lorrie Moore's Metafictional Feminism” addresses the issue of feminism and its fictionalized presence in Moore's oeuvre. In her article, Heidi Slettedahl Macpherson suggests that Moore's work offers a comic exploration of the pain of womanhood and motherhood, and of her negotiations with both feminism and postfeminism. She explores how Moore experiments with a gendered postmodern sense of identity, focussing on the fragmented self not just as a reaction against the constraints of a realist narrative, but as an opportunity to explore a "cubist" sensibility that addresses "the powers and imperfections of the imagination." ${ }^{2}$ Although ranging across Moore's stories, the principal focus of the essay is on Anagrams, which offers 
Moore's most overt play on masquerade and (re)invention. Macpherson also explores how Moore's oeuvre is suffused with women characters who attempt a variety of escapes from their presumed narrative closures and who struggle with feminism and its consequent impact on their narrated lives. The essay explores Moore's fictional(ized) feminism and her characters' resort to masquerade as a legitimate response to contemporary angst and narrative tension.

The final essay of the trio, “'A Little Ethnic Kink Is Always Good to See': Jewish Performance Anxiety and Anti-passing in the Fiction of Lorrie Moore," situates Moore's work within the context of contemporary discourses about ethnicity and post-ethnicity, focussing on her representation of Jewish characters' representations of themselves. David Brauner traces Moore's representations of Jewishness over the course of her career, arguing that it is characterized by "performance anxiety" (borrowing a phrase from Moore herself), an anxiety that manifests itself in awkward comedy and that can be read biographically, in terms of Moore's negotiations with Jewishness in her own life, or as an oblique commentary on, or reworking of, the passing trope. Although there are no conventional passing narratives in her fiction, Moore's Jewish characters tend, paradoxically, to behave as though they are passing as Jewish and in so doing they deconstruct the very notion of what Jewishness is. Their anxious performance of Jewishness might, in fact, be read as a sort of anti-passing, in that they feel compelled to appropriate for themselves an ancestral Jewishness which, at the same time, they perceive as inauthentic in the context of their modern secular American lives, whereas the protagonists of conventional passing narratives disavow an ancestral identity that they nonetheless feel, at some level, to be more authentic than the one they have assumed. Throughout Moore's fiction, Brauner argues, Jewishness fulfils a symbolic function, representing, and represented as, an "ethnic kink" that disrupts the neat demarcations of what David Hollinger has called the "ethnoracial pentagon" and whose anxious performance implies the radical idea that it is possible to pass as a member not simply of another ethnicity, but of your own. ${ }^{33}$ Just as passing narratives complicate conventional ethno-racial definitions, so Moore's anti-passing narratives, by representing Jews who represent themselves as other to themselves, as well as to WASP America, destabilize the category of Jewishness and, by implication, deconstruct the very notion of ethnic categorization.

Now in her mid-fifties, Moore has long shed the image of the precocious talent who won the Seventeen story prize with her first submission as a

${ }^{33}$ See David A. Hollinger, Post-Ethnic America: Beyond Multiculturalism (New York: Basic Books, 2005), 8. 
nineteen-year-old undergraduate, but there is still a sense that her best work may be yet to come. In that respect, this trio of essays represents by no means the final word on Moore, but rather an interim assessment of a career that is already substantial and promises much more to come. Together these three essays offer a coherent and striking exploration of Moore's work that develops new directions for future criticism and will help cement her growing reputation as one of the most original and distinctive contemporary writers. They sometimes circle around the same stories, even the same quotations, reading them in a variety of frames and picking up (and at) the nuances of Moore's sustained wordplay and careful documenting of space, of identity, of gender - and taking their cue from Moore's writerly practice, in which particular themes and ideas are reimagined from various perspectives. Thus these essays work together rather than separately, layering over multiple understandings of Moore's incisive American literature. 